\title{
Editorial
}

\section{Recent Developments in Nuclear Reverse-Genetic Manipulation that Advance Seaweed Biology in the Genomic Era}

\author{
Koji Mikami* \\ Faculty of Fisheries Sciences, Hokkaido University, Hakodate, Japan \\ ${ }^{*}$ Corresponding author: Koji Mikami, Faculty of Fisheries Sciences, Hokkaido University, 3-1-1 Minato-cho, \\ Hakodate 041-8611, Japan, Tel/Fax: +81-138-40-8899; E-mail: komikami@fish.hokudai.ac.jp
}

Received Date: 18 July 2018; Accepted Date: 23 August 2018; Published Date: 28 August 2018

Seaweeds are multicellular aquatic plants that live in intertidal and subtidal zones; notably the former has harsh changes in environmental conditions. Thus, a high level of stress tolerance is indispensable for many seaweeds to carry out normal development and growth. Seaweeds generally have a haploid-diploid sexual life-cycle in which the haploid gametophyte and diploid sporophyte alternate [1-3]. Red and brown seaweeds have a gametophyte- and sporophyte-dominant life cycle, respectively, with morphological differences between the two generations, whereas green seaweeds have morphologically indistinguishable gametophytes and sporophytes. However, little is known about the physiological and molecular systems regulating multicellularity, diphasic life-cycle and acquisition of stress tolerance in seaweeds.

Since elucidating the regulatory mechanisms of life cycle and stress tolerance is fundamental to understanding the biological strategies enabling growth and survival of seaweeds in a stressful hydrosphere, master genes regulating morphogenesis, life-cycle progression and acquisition of stress tolerance should be identified in a variety of seaweed species. To this end, it is clear that a gene-targeting manipulation is a promising technique for direct analysis of gene function [4]. However, such a method has not been established in seaweeds, despite much effort by phycologists to develop reverse-genetic techniques such as gene-targeting disruption (knock-out) and insertion (knock-in) by homologous recombination via stable transformation. To contribute toward establishment of genetic manipulation systems, I summarize here the current progress in genome analysis and development of reverse-genetic methods in seaweeds.

The presence of master genes for morphogenesis and life cycle has been confirmed by genetic studies using mutants showing aberrant morphology and developmental processes. For instance, in the model brown seaweed species Ectocarpus silicu- losus, the étoile (etl) mutant showed enhanced branching with arrest of apical growth in sporophytes [5]; and two life-cycle mutants were reported, the immediate upright (imm) and the ouroboros (oro) mutants with partial and complete conversion, respectively, of the sporophyte to the gametophyte [6,7]. In addition, slender and lumpy mutants showed a high growth rate with a lack of cell differentiation and with cell aggregation due to alteration of polarized cell division, respectively, in the green macroalga Ulva mutabilis [8]. However, despite the isolation of numerous mutants in brown, green and red seaweeds [8], identifying the genes responsible for their phenotypes is very difficult, because the mutants were obtained by spontaneous and chemical mutagenesis. Thus, genome sequencing was required as an indirect approach. The first sequencing analysis of the nuclear genome in seaweed was for E. siliculosus [9], which enabled identification of a gene encoding IMM by positional cloning [10]. This represents a strong contribution of genome information toward understanding molecular systems regulating development and life cycle. The same approach is also expected to result in identification of genes responsible for the etl and oro mutant phenotypes.

Following the E. siliculosus genome analysis, the nuclear genome was sequenced for several red and brown seaweeds, especially for economic species such as Nori (Laver), Kombu, Mozuku and agarophytes (Table 1). In relation to this progress, genome-wide gene expression profiling (also known as transcriptome or RNAseq analysis) was also performed extensively for simultaneous identification of genes induced and repressed under various kinds of environmental stress conditions or in different life-cycle generations (for example, [19-27]). Therefore, much information on genes and their expression profiles has been gained as a result of genome and transcriptome analyses.

As mentioned previously, we cannot directly analyze the functions of genes of interest at present because of the lack of genome 
Citation: Koji Mikami (2018) Recent Developments in Nuclear Reverse-Genetic Manipulation that Advance Seaweed Biology in the Genomic Era. J Aquat Res Mar Sci 2018: 39-42. DOI: https://doi.org/10.29199/ARMS.101019.

\begin{tabular}{|c|c|c|c|c|}
\hline Species & Genome size $(\mathrm{Mb})$ & Gene no & GC content $(\%)$ & Ref \\
\hline \multicolumn{5}{|l|}{ Brown seaweed } \\
\hline Ectocarpus siliculosus & 214 & 16,256 & 53.6 & [9] \\
\hline Saccharina japonica (Kombu) & 545 & 18,733 & 49.1 & [11] \\
\hline Cladosiphon okamuranus (Mozuku) & 140 & 13,640 & 54 & {$[12]$} \\
\hline \multicolumn{5}{|l|}{ Red seaweed } \\
\hline \multicolumn{5}{|l|}{ Bangiophyceae } \\
\hline Pyropia yezoensis (Nori, Laver) & 43 & 10,327 & 63.6 & [13] \\
\hline Porphyra umbilicalis (Nori, Laver) & 87 & 13,360 & 65.8 & {$[14]$} \\
\hline \multicolumn{5}{|l|}{ Floridophyceae } \\
\hline Chondrus crispus & 105 & 9,606 & 52 & [15] \\
\hline Gracilariopsis chorda & 92 & 10,805 & 49.3 & {$[16]$} \\
\hline Gracilaria changii & 36 & 10,912 & 50.6 & {$[17]$} \\
\hline \multicolumn{5}{|l|}{ Green seaweed } \\
\hline \multicolumn{5}{|l|}{ Mating type locus } \\
\hline Ulva partita mt- & 1.0 & 46 & & {$[18]$} \\
\hline Ulva partita mt+ & 1.5 & 67 & & {$[18]$} \\
\hline
\end{tabular}

Table 1: Current status of nuclear genome sequencing in seaweeds (Gracilariopsis chorda and Gracilaria changii of Floridophyceae are agarophytes. Analysis of Ulva partita has been performed for only mating type loci of $\mathrm{mt}-$ and $\mathrm{mt}+$ strains, whose GC contents were not mentioned in the reference).

manipulation techniques in seaweeds $[28,29]$. Nonetheless, two significant achievements toward development of reverse-genetic experimental systems were published in 2013 and 2015. One was the establishment of a functional RNA interference method using embryos of the brown alga Fucus serratus [30], in which microinjection of double-strand RNA (dsRNA) corresponding to the $\alpha$-tubulin gene transcript reduced intracellular microtubules and arrested growth of injected embryos. This was the first report of gene-targeting down-regulation in seaweeds due to the functional significance of dsRNA and is expected to contribute to analysis of gene function in developmental regulation of Fucaceae. However, applying this method to other seaweeds is likely to be very difficult, because vegetative cells and spores in most other seaweeds are much smaller than in Fucus embryos and so are likely to be killed by injection using a needle. Thus, microinjection is currently restricted to Fucus embryos.

The second method is confirmation of integration of a foreign plasmid into the genome of the green seaweed U. mutabilis [31]. The plasmid containing the bleomycin resistance (ble) or ble-gfp fusion coding region sandwiched by the $5^{\prime}$ - and $3^{\prime}$-regions of the nuclear $r b c S$ gene was successfully introduced into genomes of gametes, spores and protoplasts by polyethylene glycol (PEG) method, in which the plasmid DNA was randomly integrated into the genome of antibiotic-resistant cells. In addition, since some transgenic lines showed aberrant phenotypes, random integration seems to have potential to disrupt genes involved in regulation of morphogenesis. Thus, so-called tagging lines, a collection of mutants showing abnormal morphology or devel- opment, might be generated by this approach, by which genes responsible for mutant phenotypes may be isolated more easily than for the positional cloning performed in E. siliculosus. However, in turn, random integration of a plasmid indicates an inability for gene-targeted modification using this method. It is therefore necessary to develop a powerful reverse-genetic system, such as a homologous recombination-based gene modification, to enable analysis of the functions of genes of interest. Alternatively, genome editing is expected to develop based on the PEG method because only transfer of a foreign gene to the nucleus, and not integration into the genome, is required for transient expression of genes in plasmids for genome editing.

Despite above significant progresses, gene-targeting homologous recombination and genome editing have not been established in seaweeds at present. Thus, functional analysis of genes involved in morphogenesis, development, life cycle and stress tolerance have not yet reported, except for the E. siliculosus DISTAG/TBC$C d 1$ gene controlling production of rhizoids, which was recently isolated by positional cloning [32]. It is however clear that seaweed genomes can accept foreign genes by integration [31]. Thus, homologous recombination is expected to be successful, if efficient selection of transformed cells or tissues is available, because seaweeds usually tolerate high concentrations of antibiotics [33]. Identification of an excellent selection marker for individual seaweed species could accelerate establishment of transformation systems based on gene-targeting modifications. In addition, to establish genome editing based on the CRISPR/ Cas9 system, a promoter of the U6 or U3 small nuclear RNA 
Citation: Koji Mikami (2018) Recent Developments in Nuclear Reverse-Genetic Manipulation that Advance Seaweed Biology in the Genomic Era. J Aquat Res Mar Sci 2018: 39-42. DOI: https://doi.org/10.29199/ARMS.101019.

(snRNA) gene should be isolated to express a guide RNA [4]; however, it is currently difficult to identify these genes in genome and transcriptome data. In contrast, since microinjection of proteins and RNAs is possible, it is plausible that genome editing might be established at least in Fucus embryos by injection of both Cas9 protein and guide RNA into the nucleus. Accordingly, future studies toward establishing reverse-genetic manipulations in seaweeds other than Fucus embryos should focus on identifying selection markers and cloning promoter regions of snRNA genes. Progress in these approaches should provide essential techniques contributing to rapid development of seaweed biology in the genomic era.

\section{References}

1. Thornber CS (2006) Functional properties of the isomorphic biphasic algal life cycle. Integr Comp Biol 46: 605-614.

2. Bast $F(2014)$ An illustrated review on cultivation and life history of agronomically important seaplants. Seaweed: mineral composition, nutritional and antioxidant benefits and agricultural uses. Nova Publishers, New York pp. 39-70.

3. Cock JM, Godfroy O, Macaisne N, Peters AF, Coelho SM (2014) Evolution and regulation of complex life cycles: a brown algal perspective. Curr Opin Plant Biol 17: 1-6.

4. Mikami K (2014) A technical breakthrough close at hand: feasible approaches toward establishing a gene-targeting genetic transformation system in seaweeds. Front Plant Sci 5: 498.

5. Le Bail A, Billoud B, Le Panse S, Chenivesse S, Charrier B (2011) ETOILE regulates developmental patterning in the filamentous brown alga Ectocarpus siliculosus. Plant Cell 23: 1666-1678.

6. Peters AF, Scornet D, Ratin M, Charrier B, Monnier A, Merrien Y, et al. (2008) Life-cycle-generation-specific developmental processes are modified in the immediate upright mutant of the brown alga Ectocarpus siliculosus. Development 135: 1503-1512.

7. Coelho SM, Godfroy O, Arun A, Le Corguillé G, Peters AF, et al. (2011) OUROBOROS is a master regulator of the gametophyte to sporophyte life cycle transition in the brown alga Ectocarpus. Proc Natl Acad Sci USA 108: 11518-11523.

8. Charrier B, Rolland E, Gupta V, Reddy CR (2015) Production of genetically and developmentally modified seaweeds: exploiting the potential of artificial selection techniques. Front Plant Sci 6: 127.

9. Cock JM, Sterck L, Rouzé P, Scornet D, Allen AE, et al (2010). The Ectocarpus genome and the independent evolution of multicellularity in brown algae. Nature 465: 617-621.

10. Macaisne N, Liu F, Scornet D, Peters AF, Lipinska, et al. (2017) The Ectocarpus IMMEDIATE UPRIGHT gene encodes a member of a novel family of cysteine-rich proteins that have an unusual distribution across the eukaryotes. Development 144: 409-418.

11. Ye N, Zhang X, Miao M, Fan X, Zheng Y, et al. (2015) Saccharina genomes provide novel insight into kelp biology. Nat Commun 6: 6986.

12. Nishitsuji $K$, Arimoto $A$, Iwai $K$, Sudo $Y$, Hisata $K$, Fujie $M$, et al (2016). A draft genome of the brown alga, Cladosiphon okamuranus, S-strain: a platform for future studies of 'mozuku'biology. DNA Res 23: 561-570.
13. Nakamura Y, Sasaki N, Kobayashi M, Ojima N, Yasuike M, Shigenobu Y, et al. (2013) The first symbiont-free genome sequence of marine red alga, Susabi-nori (Pyropia yezoensis). PloS one 8: e57122.

14. Brawley SH, Blouin NA, Ficko-Blean E, Wheeler GL, Lohr M, Goodson HV, et al. (2017) Insights into the red algae and eukaryotic evolution from the genome of Porphyra umbilicalis (Bangiophyceae, Rhodophyta). Proc Natl Acad Sci 114: E6361-E6370.

15. Collén J, Porcel B, Carré W, Ball SG, Chaparro C, Tonon T, et al. (2013) Genome structure and metabolic features in the red seaweed Chondrus crispus shed light on evolution of the Archaeplastida. Proc Nat Acad Sci 110: 5247-5252.

16. Lee J, Yang EC, Graf L, Yang JH, Qiu H, Zel Zion, et al. (2018) Analysis of the draft genome of the red seaweed Gracilariopsis chorda provides insights into genome size evolution in Rhodophyta. Mol Bio Evol 8: 1869-1886.

17. Ho CL, Lee WK, Lim EL (2018) Unraveling the nuclear and chloroplast genomes of an agar producing red macroalga, Gracilaria changii (Rhodophyta, Gracilariales). Genomics 110: 124-133.

18. Yamazaki T, Ichihara $\mathrm{K}$, Suzuki R, Oshima K, Miyamura $\mathrm{S}$ et al. (2017) Genomic structure and evolution of the mating type locus in the green seaweed Ulva partita. Sci Rep 7: 11679.

19. Dittami SM, Scornet D, Petit JL, Ségurens B, Da Silva C, Corre, et al. (2009) Global expression analysis of the brown alga Ectocarpus siliculosus (Phaeophyceae) reveals large-scale reprogramming of the transcriptome in response to abiotic stress. Genome Biol 10: R66.

20. Heinrich S, Valentin K, Frickenhaus S, John U, Wiencke C (2012) Transcriptomic analysis of acclimation to temperature and light stress in Saccharina latissima (Phaeophyceae). PLoS One 7: e44342.

21. Zhang X, Ye N, Liang C, Mou S, Fan X, Xu J, et al. (2012) De novo sequencing and analysis of the Ulva linza transcriptome to discover putative mechanisms associated with its successful colonization of coastal ecosystems. BMC genomics 13: 565 .

22. Choi S, Hwang MS, Im S, Kim N, Jeong WJ, et al. (2013) Transcriptome sequencing and comparative analysis of the gametophyte thalli of Pyropia tenera under normal and high temperature conditions. J Appl Phycol 25: 1237-1246.

23. Luo Q, Zhu Z, Zhu Z, Yang R, Qian F, Chen H, et al (2014) Different responses to heat shock stress revealed heteromorphic adaptation strategy of Pyropia haitanensis (Bangiales, Rhodophyta). PloS one 9: e94354.

24. Sun P, Mao Y, Li G, Cao M, Kong F, Wang L, et al. (2015) Comparative transcriptome profiling of Pyropia yezoensis (Ueda) MS Hwang \& HG Choi in response to temperature stresses. BMC Genomics 16: 463 .

25. Wang W, Li H, Lin X, Yang S, Wang Z, Fang B (2015) Transcriptome analysis identifies genes involved in adventitious branches formation of Gracilaria lichenoides in vitro. Sci Rep 5: 17099.

26. Wang L, Mao Y, Kong F, Cao M, Sun P (2015) Genome-wide expression profiles of Pyropia haitanensis in response to osmotic stress by using deep sequencing technology. BMC Genomics 16: 1012.

27. Cao M, Wang D, Mao Y, Kong F, Bi G, Xing Q, et al. (2017) Integrating transcriptomics and metabolomics to characterize the regulation of EPA biosynthesis in response to cold stress in seaweed Bangia fuscopurpurea. PloS one 12: e0186986. 
Citation: Koji Mikami (2018) Recent Developments in Nuclear Reverse-Genetic Manipulation that Advance Seaweed Biology in the Genomic Era. J Aquat Res Mar Sci 2018: 39-42. DOI: https://doi.org/10.29199/ARMS.101019.

28. Mikami K, Hirata R, Takahashi M, Uji T, Saga N (2011) Transient transformation of red algal cells: breakthrough toward genetic transformation of marine crop Porphyra species Intech Open pp. 241258.

29. Mikami K (2013) Current advances in seaweed transformation. Intech Open pp. 323-347.

30. Farnham G, Strittmatter M, Coelho S, Cock JM, Brownlee C (2013) Gene silencing in F ucus embryos: developmental consequences of RNA i mediated cytoskeletal disruption J Phycol 49: 819-829.
31. Oertel W, Wichard T, Weissgerber A (2015) Transformation of Ulva mutabilis (Chlorophyta) by vector plasmids integrating into the genome. J Phycol 51: 963-979.

32. Godfroy O, Uji T, Nagasato C, Lipinska AP, Scornet D, Peters AF, et al. (2017) DISTAG/TBCCd1 is required for basal cell fate determination in Ectocarpus. Plant Cell 29: 3102-3122.

33. Takahashi M, Mikami K, Mizuta H, Saga N (2011) Identification and efficient utilization of antibiotics for the development of a stable transformation sysem in Porphyra yezoensis (Bangiales, Rhodophyta). J Aquac Res Develop 2: 118.

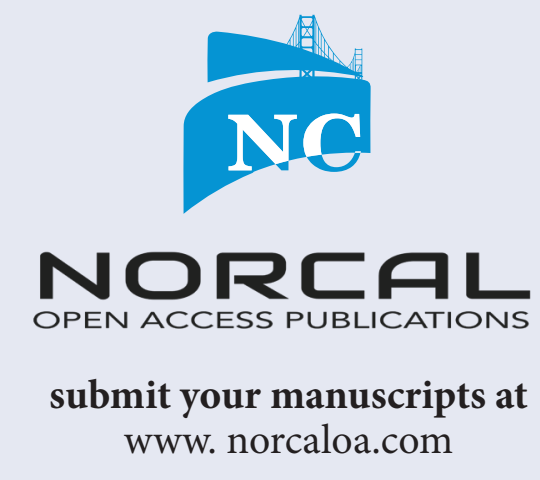

J Aquat Res Mar Sci 2018: 39-42. 